\title{
Sentinel node mapping in endometrial cancer
}

\author{
Giorgio Bogani, Antonino Ditto, Valentina Chiappa, Francesco Raspagliesi \\ Department of Gynecologic Oncology, IRCCS National Cancer Institute, Milan, Italy \\ Correspondence to: Giorgio Bogani, MD, PhD. Gynecologic Oncology Unit, National Cancer Institute, Via Venezian 1, 20133 Milan, Italy. \\ Email: giorgio.bogani@istitutotumori.mi.it. \\ Comment on: Farazestanian M, Yousefi Z, Zarifmahmoudi L, et al. Concordance Between Intracervical and Fundal Injections for Sentinel Node \\ Mapping in Patients With Endometrial Cancer?: A Study Using Intracervical Radiotracer and Fundal Blue Dye Injections. Clin Nucl Med \\ 2019;44:e123-e127.
}

Submitted Apr 07, 2019. Accepted for publication Apr 29, 2019.

doi: $10.21037 /$ tcr.2019.04.23

View this article at: http://dx.doi.org/10.21037/tcr.2019.04.23

Sentinel node mapping in endometrial cancer staging has gained popularity among gynecologic oncology community. Although endometrial cancer represents the most common gynecological malignancy in developed countries several features of its management are still objects of debates. In particular the role of lymphadenectomy is still unclear (1). Accumulating data underlined that sentinel node mapping is not inferior to conventional lymphadenectomy $(2,3)$. However, sentinel node mapping seems to be superior to conventional lymphadenectomy. The adoption sentinel node mapping instead of lymphadenectomy reduces the risk of developing surgery-related morbidity. Moreover, sentinel node mapping allows detecting patients with low volume disease (i.e., micrometastases and isolated tumor cells) otherwise missing without pathological ultrastaging. Recent data underlined that low volume disease not identifiable with conventional lymphadenectomy accounts for $30 \%$ of all node positive endometrial cancer (4).

The uterus has a complex lymphatic drainage. Owing to the importance to perform an accurate mapping, surgeons still debate on the preferred site of injection for the detection of sentinel nodes. Although cervical injection is a simple procedure and guarantees a high detection of pelvic nodes in the pelvic area (in both emi-pelvis), corporal infection ensures delineation of lymphatic drainage from the tumor area, thus achieving accurate detection of sentinel nodes.

By this point of view cervical injection is aimed to detect the first nodes draining the lymph from the uterus; while corporal injection is aimed to detect the first nodes draining the lymph from the uterus. In most cases they are the same nodes, but few patients (with skip lesions) might benefit from peri-tumoral injection.

In the present paper, Farazestanian et al. investigated how cervical and fundal injection might influence sentinel node detection rates. The authors performed (in the same 45 patients) a head to head comparison of intra-cervical radiotracer and fundal blue dye injections (5). They observed that lymphatic drainage in the pelvic area from the uterine cervix matches with the lymphatic drainage in the pelvic area from the uterine corpus. Additionally, paraaortic sentinel nodes were detected in $2(4.4 \%)$ and 10 (22.2\%) patients having cervical and fundal injections (5). These findings are concordant with the data reported by Cormier et al., observing that corporal injection improve para-aortic detection rate in comparison with cervical injection (6). Para-aortic mapping was most frequent after corporeal injection techniques (39\%), and was higher after deep vs. standard cervical injection (17\% vs. $2 \%)$ (6). The ongoing prospective randomized SNEC trial will clarify pros and cons of adopting cervical and hysteroscopic injection for sentinel node mapping for endometrial cancer staging (7). Further studies are warranted to address what are the most useful techniques for detecting lymphatic diseases in endometrial cancer. Moreover, we auspicate that the adoption of genetic/molecular disease profiling would useful, per se, to tailor treatments independently to staging procedures, thus improving patients' care.

\section{Acknowledgments}

Funding: None. 


\section{Footnote}

Provenance and Peer Review: This article was commissioned and reviewed by the Section Editor Hengwei Liu, MD, PhD (Department of Obstetrics and Gynecology, Union Hospital, Tongji Medical College, Huazhong University of Science and Technology, Wuhan, China).

Conflicts of Interest: The authors have completed the ICMJE uniform disclosure form (available at http://dx.doi. org/10.21037/tcr.2019.04.23). The authors have no conflicts of interest to declare.

Ethical Statement: The authors are accountable for all aspects of the work in ensuring that questions related to the accuracy or integrity of any part of the work are appropriately investigated and resolved.

Open Access Statement: This is an Open Access article distributed in accordance with the Creative Commons Attribution-NonCommercial-NoDerivs 4.0 International License (CC BY-NC-ND 4.0), which permits the noncommercial replication and distribution of the article with the strict proviso that no changes or edits are made and the original work is properly cited (including links to both the formal publication through the relevant DOI and the license). See: https://creativecommons.org/ licenses/by-nc-nd/4.0/.

Cite this article as: Bogani G, Ditto A, Chiappa V, Raspagliesi F. Sentinel node mapping in endometrial cancer. Transl Cancer Res 2019;8(6):2218-2219. doi: 10.21037/tcr.2019.04.23

\section{References}

1. Bogani G, Dowdy SC, Cliby WA, et al. Management of endometrial cancer: issues and controversies. Eur J Gynaecol Oncol 2016;37:6-12.

2. Bogani G, Murgia F, Ditto A, et al. Sentinel node mapping vs. lymphadenectomy in endometrial cancer: A systematic review and meta-analysis. Gynecol Oncol 2019;153:676-83.

3. Frumovitz M, Plante M, Lee PS, et al. Near-infrared fluorescence for detection of sentinel lymph nodes in women with cervical and uterine cancers (FILM): a randomised, phase 3, multicentre, non-inferiority trial. Lancet Oncol 2018;19:1394-403.

4. Bogani G, Mariani A, Paolini B, et al. Low-volume disease in endometrial cancer: The role of micrometastasis and isolated tumor cells. Gynecol Oncol 2019;153:670-5.

5. Farazestanian M, Yousefi Z, Zarifmahmoudi L, et al. Concordance Between Intracervical and Fundal Injections for Sentinel Node Mapping in Patients With Endometrial Cancer?: A Study Using Intracervical Radiotracer and Fundal Blue Dye Injections. Clin Nucl Med 2019;44:e123-e127.

6. Cormier B, Rozenholc AT, Gotlieb W, et al. Sentinel lymph node procedure in endometrial cancer: A systematic review and proposal for standardization of future research. Gynecol Oncol 2015;138:478-85.

7. Bogani G, Raspagliesi F. Does the adoption of sentinel node mapping allow to design a new trial testing the value of retroperitoneal staging in endometrial cancer? J Gynecol Oncol 2019;30:e68. 